\title{
Endogenous RNA Polymerase Activity of Liver Chromatin in Rats Maintained under Controlled Feeding Schedules
}

Nucleolar and nucleoplasmatic RNA synthesis measured in whole purified nuclei undergoes daily systematic variations in the liver of rats maintained under controlled feeding schedules ${ }^{1}$. The daily modulation of RNA synthesis seems to depend on a regulatory mechanism involving the template availability of liver chromatin for the DNA-dependent RNA polymerase II, rather than the availability of the enzyme itself ${ }^{2}$.

We report in this communication the behaviour of the endogenous RNA polymerase activity of liver chromatin in rats maintained under controlled feeding schedules.

Methods. Male Wistar derived albino rats obtained from the departmental animal house, each weighing $200 \pm 15 \mathrm{~g}$, were housed since weaning, in an air-conditioned windowless room under an inverted and displaced lighting schedule (lights on from $21.00 \mathrm{~h}$ to $09.00 \mathrm{~h}$, dark from $09.00 \mathrm{~h}$ to $21.00 \mathrm{~h}$ ). The food, a purine chow lab diet, was supplied at $09.00 \mathrm{~h}$ and withdrawn at $17.00 \mathrm{~h}$ according to the ' $8+16$ ' feeding schedule developed by PotTer et al. ${ }^{3}$. Water was supplied ad libitum.

Rat liver chromatin was extracted as indicated by BUTTERWORTH et al. ${ }^{4}$ from the liver nuclei purified according to WIDNELL and TATA ${ }^{5}$. The assay of endogenous RNA polymerase was carried out according to Cox et al. ${ }^{6}$.

All assays contained a final volume of $0.75 \mathrm{ml}, 25 \mathrm{mM}$ Tris- $\mathrm{HCl}, \mathrm{pH} 8.0,1 \mathrm{mM} \mathrm{MnCl}_{2}, 0.5 \mathrm{~m} M$ dithiothreitol,

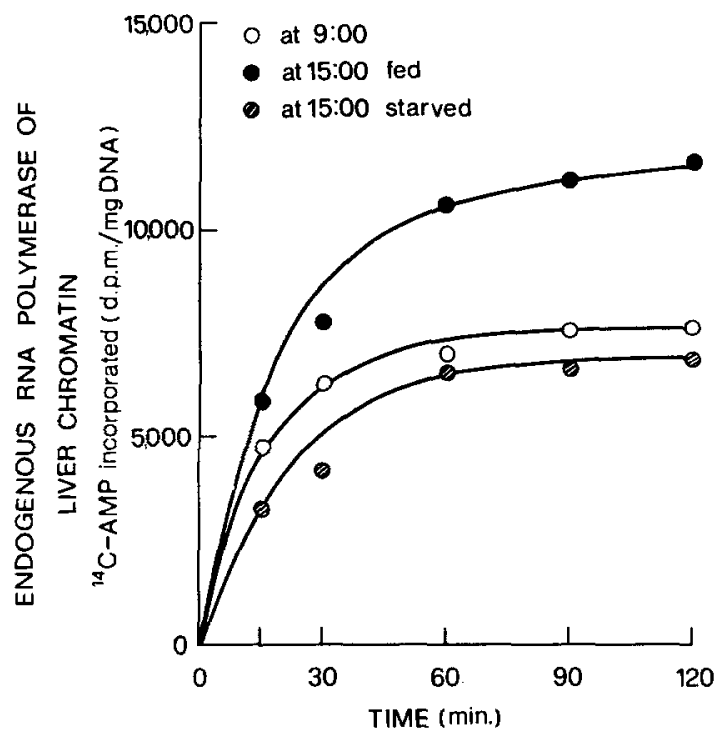

Comparison of the kinetics of endogenous RNA polymerase activity of chromatin isolated from the liver of rats maintained under controlled feeding schedules at different times of day and in different feeding conditions. Assay conditions were as described in the text.
$0.9 \mu$ mole each of GTP, CTP, UTP, $0.045 \mu$ mole ATP, $0.015 \mu$ mole ${ }^{14} \mathrm{C}$-ATP, $250 \mathrm{mM}\left(\mathrm{NH}_{4}\right)_{2} \mathrm{SO}_{4}$, aliquot of chromatin containing 95 to $110 \mu \mathrm{g}$ DNA.

The reaction was stopped by addition of $1 \mathrm{mg}$ of albumin and $5 \mathrm{ml}$ of $0.5 \mathrm{M} \mathrm{HClO}$. The precipitate was collected on Whatman GF/C filters and radioactivity measured in a Nuclear-Chicago liquid scintillation spectrometer with a counting efficiency of $80 \%$. DNA was determined by the diphenylamine reaction of BURTON?

Results and discussion. The endogenous RNA polymerase activity of liver chromatin, measured at high ionic strength, is considered a measure of the elongation steps in the genetic transcription ${ }^{4,6}$. In fact the binding of the enzyme to the chromatin (initiation step) and the release and reinitiation of new RNA chains (termination) are inhibited by the high ionic strength in the incubation medium, while the elongation is not sensitive.

The Figure reports the kinetics of endogenous RNA synthesis for $09.00 \mathrm{~h}$ chromatin, and $15.00 \mathrm{~h}$ chromatin from both fed and starved rats. We have extracted the liver chromatin at these times of day because in our experimental conditions $09.00 \mathrm{~h}$ represents the background level of RNA polymerase activity, while $15.00 \mathrm{~h}$ the top level when the rats are fed since $09.00 \mathrm{~h}$, or again the background level when the rats are starved on the day of experiment ${ }^{1}$. Both the initial rate of RNA synthesis and the quantity of RNA synthesized after $2 \mathrm{~h}$ are increased in the rats fed since $09.00 \mathrm{~h}$. The differences in RNA polymerase activity were not due to differences in ribonuclease activity. In fact dilution of the radioactive $\mathrm{ATP}^{3}$ at 60 min point, and comparison with undiluted assays shows that for all chromatins RNA synthesis is stopped, and $1 \mathrm{~h}$ later the degradation of the radioactive RNA product is negligible.

Our present results show an increase of about $70 \%$ of the elongation step in the transcription process, and this increase is bound to the food intake. This supports the point of view put forward in a previous paper ${ }^{2}$ that the modulation of nucleoplasmatic RNA synthesis is achieved by modulating the template availability rather than the enzyme itself.

Riassunto. E stata misurata la attività RNA polimerasica endogena della cromatina estratta dal fegato di ratti mantenuti in condizioni ambientali controllate. I risultati mostrano un aumento dell'attività endogena del $70 \%$ determinata dall'assunzione del cibo.

B. Barbiroli, B. Tadolini, M. S. Moruzzi and M. G. Monti

Istituto di Chimica Biologica dell'Università di Bologna, Via Irnerio, 48, I-40126 Bologna (Italy), 19 September 1973.
1 B. Barbiroli, M. S. Moruzzi, M. G. Monti and B. Tadolini, Biochim. Biophys. Res. Commun., in press (1973).

2 B. Barbiroli, M. G. Monti, B. Tadolini and M. S. Moruzzi, FEBS Letters, in press (1973).

V. R. Potter, E. F. Baril, M. Watanabe and E. D. Whittle, Fedn. Proc. 27, 1238 (1968).
${ }^{4}$ P. H. W. Butterworth, R. F. Cox and C. J. Chesterton, Eur. J. Biochem. 23, 229 (1971).

s C. C. WidNeli and J. R. TAta, Biochem. J. 92, 313 (1964).

6 R. F. Cox, M. E. Haines and N. H. Carey, Eur. J. Biochem. 32, 513 (1973).

' K. Burton, Biochem. J. 62, 315 (1956). 